\title{
Flood response to rainfall variability during the last 2000 years inferred from the Taravilla Lake record (Central Iberian Range, Spain)
}

Ana Moreno ${ }^{1,2}$, Blas L. Valero-Garcés ${ }^{2}$, Penélope González-Sampériz ${ }^{2}$ and Mayte Rico ${ }^{2}$ ${ }^{1}$ Limnological Research Center, Department of Geology and Geophysics, University of Minnesota, 310 Pillsbury Drive SE, Minneapolis, MN 55455, USA. moren079@umn.edu

${ }^{2}$ Instituto Pirenaico de Ecología (C.S.I.C.), Apdo 202, 50080 Zaragoza, Spain. amoreno@ipe.csic.es; $\underline{\text { blas@ @ipe.csic.es; pgonzal@ipe.csic.es; mayterico@ipe.csic.es }}$

Keywords: paleoflood reconstructions, Little Ice Age, solar variability, XRF core scanner. 


\begin{abstract}
A sedimentological, geochemical and palynological study of the Taravilla Lake sequence (Central Iberian Range, NE Spain) provides a detailed record of allocthonous terrigenous layers that intercalate within the lacustrine sediments during the last 2000 years. These terrigenous layers are interpreted as the result of extreme hydrological events that resulted in a higher clastic input to the basin. Anthropogenic influence caused by fires or deforestation is discarded as the main factor triggering the generation of these layers since human impact, deduced from the pollen reconstruction, was minimum when the terrigenous layers reach the maximum frequency. The reconstructed occurrence of these events defined from the Taravilla Lake record is coherent with the paleoflood history of the Tagus River, characterized by a notable increase of extreme events at the beginning of the Little Ice Age. The Taravilla record suggests a relationship between the occurrence of extreme hydrological events, solar variability and the North Atlantic Oscillation for the NE Iberian Peninsula.
\end{abstract}




\section{Introduction}

The frequency and intensity of extreme weather events is a likely candidate to undergo an important increase in scenarios of future global warming (McCarthy et al. 2001). Recently, more research has been focused on those extreme events due to the often large loss of human life and exponentially increasing costs associated with them (Changnon and Easterling 2000). However, the lack of high quality long-term records and the difficulty to decipher the relative roles of climatic variability and human impact throughout the Holocene are major problems on examining the long-term climate record for changes in weather extremes (Oldfield 2005). In this context, it has proved particularly difficult to study the variability in the frequency and intensity of extreme storms with exceptional rainfall (Noren et al. 2002).

In the Mediterranean region, and particularly in the Iberian Peninsula, due to the high sensitivity to moisture variations, future scenarios of global warming predict even higher severity of floods and droughts (Houghton et al. 2001). Palaeoclimate archives from this area for the last millennia are needed in order to understand the natural climate variability, detect the effect of human land-use activities, and find out the response of the hydrological systems and landscapes to extreme events. A major problem in historical times is to distinguish from the sedimentary signature of extraordinary events, such as floods, the effects of climate variability from the changing nature of land cover, and the human- management and modifications of the hydrological systems (LópezMoreno et al. 2006; Nesje et al. 2001). High resolution lake sediment-based studies can help to document and improve our understanding of these complex interactions since lake may record the flood history of inlet rivers (Nesje et al. 2001; Thorndycraft et al. 1998). 
Increased clastic input recorded in some lake records from the Iberian Peninsula points to fluctuating but higher lake levels during the last 800 years and an increase in sediment delivery (González-Sampériz et al. in press; Martín-Puertas et al. in press; Morellón et al. in press; Riera et al. 2004). In addition, a long database produced from the stratigraphic record of slackwater flood deposits in the Tagus River Basin (Benito et al. 2003a; Benito et al. 2003; Thorndycraft and Benito 2006) demonstrates an increase in the frequency of flood episodes during the last 150 years. Discriminating if this positive water balance is related to an increase in precipitation or/and an augment in torrentially favoured by less vegetation cover is still under discussion (Riera et al. 2004).

Although the climate forcing mechanism to produce changes in the frequency of flood events during the last millennia is not yet clear, a relation with solar variability has been recently suggested (Vaquero 2004). The available series of the annual number of Sun spots indicate that some of the solar irradiance maxima intervals (Bard et al. 2000) correspond to an increase number of sun spots (Ogurtsov et al. 2002; Vaquero et al. 2002). It has been also observed that some cold climatic intervals, such as the Little Ice Age (LIA), correspond to periods where sun spot frequency and, then, solar irradiance are minima (Bard and Frank 2006). In fact, during the LIA, four of the more evident minima in solar activity occurred (Wölf, Spörer, Maunder, and Dalton Minima). At a different time scale, periods of solar maxima are believed to be related to low values in the North Atlantic Oscillation (NAO) index (Kirov and Georgieva 2002), which are associated with high winter precipitation and river flow in the Atlantic basins of the Iberian Peninsula (Trigo et al. 2004). Nevertheless, in order to explore the climate forcing mechanisms to produce extreme flood events during the last millennia, more records from the Iberian Peninsula are needed. 
Palaeoflood records from many regions have shown extreme hydrological events to be more sensitive to climatic change than modal-range hydrological events (Knox 2000). In this paper we investigate the flood record in Taravilla Lake $\left(40^{\circ} 39^{\prime} \mathrm{N}\right.$; $1^{\circ} 59^{\prime} \mathrm{W} ; 1100 \mathrm{~m}$ asl), a travertine-barrage dammed lake located in the headwaters of the Tagus River and characterized by high clastic inputs to the lake associated to extreme rainfall events. The Taravilla Lake provides an opportunity to evaluate the lake response to extreme hydrological events with the known paleoflood frequency reconstructed from the Tagus Basin (Benito et al. 2003a; Benito et al. 2003; Thorndycraft and Benito 2006). A previous paleolimnological study found a similar response of the Taravilla Lake and theTagus River for the last 2000 years, although the resolution and the time control of the Taravilla sequence was poor (Valero-Garcés et al. in press). In this paper, we focus in the identification and dating of paleoflood events from the Taravilla sequence with new cores, that enable a more detailed study of the paleoflood frequencies and the possible forcing mechanisms.

\section{Study site}

The Upper Tagus River valley is located in the Serranía de Cuenca, in the Western Branch of the Iberian Range (northeastern Spain). The regional geology is dominated by Mesozoic (Jurassic and Cretaceous) carbonates overlying clastic Triassic formations and folded and fractured during the Alpine orogeny. Surface karstic morphologies (sinkholes, dolines and poljes) are common, and tufa deposits occur in the Tagus River valley and associated to springs (Valero-Garcés et al., in press). The Upper Cretaceous carbonate formations constitute the main regional aquifer; most springs are located at 
the contact with the underlying less permeable Jurassic formations, as is the case with the Taravilla spring that feeds the lake and the tufa structures.

The Taravilla Lake $\left(40^{\circ} 39^{\prime} \mathrm{N} ; 1^{\circ} 59^{\prime} \mathrm{W} ; 1100 \mathrm{~m}\right.$ a.s.1.) has a 2.11 ha surface area, and $11 \mathrm{~m}$ maximum water depth (Figure 1A and 1B). Only one permanent spring occurs in the eastern margin, but most likely there are more underwater springs. During wet periods, the springs related to the tufa buildup in the eastern margin are also functional. The northeastern creek drains a relatively large watershed $\left(5.5 \mathrm{~km}^{2}, 549.5 \mathrm{ha}\right)$, but the inlet is only functional during wet periods (Figure 1A and 1B). The only outlet, located at the southeastern margin of the barrage tufa, drains the Laguna de Taravilla waters into the Tagus River, and becomes non functional during dry periods. The lake and spring waters are calcium and carbonate -rich, with some seasonal variability, but very similar in composition (Valero-Garces et al., in press).

The regional climate is of Mediterranean type with strong continental influence; winter temperatures are low (average December and January temperature lower than $2^{\circ}$ C), summers are short and relatively warm (average August temperature around $20^{\circ} \mathrm{C}$ ) (Figure 1C). Average annual rainfall is about $700 \mathrm{~mm}$, although inter annual variability is large (Figure 1D, for winter precipitation). Rainfall is controlled by the westerly winds associated with cold fronts, and some rain shadow effect due to the location in the eastern slope of the Iberian Range. During the summer the subtropical Azores anticyclone blocks moisture from the west. However, also during summer and at the beginning of the fall, high-intensity (highly convective) storms typically occur. As shown in Figure 1D, winter precipitation is directed influenced by the North Atlantic Oscillation (NAO) index: higher rainfall occurs when NAO is low and the westerly belt is located southwards, directly influencing the Iberian Peninsula. 
Almost $75 \%$ of the watershed is forested, and the vegetation corresponds to the supra Mediterranean subhumid type (Peinado-Lorca and Martínez-Parras, 1987). Pine is dominant (more than half of the total surface of the Upper Tagus River Natural Park), with Pinus nigra, Pinus sylvestris and Pinus pinaster as the main species, but there are also some well preserved patches of Juniperus thurifera, with Quercus ilex rotundifolia, Quercus faginea, and/or Quercus pyrenaica, depending the altitude and orientation of the different locations. Meadows for grazing and cultivated areas take up an important extension of the Quercus sp. potential areas. Isolated deciduous trees (Corylus, Fraxinus, Acer, Betula, Alnus, and others) are restricted to northern slopes and humid gorges. Phragmites sp., Juncaceae and Cyperaceae formations surround the Taravilla Lake. A large wetland develops towards the NE of the lake (Figure 1A and 1B).

\section{Material and methods}

The composite sequence from the Taravilla Lake presented here comes from two cores (TAR04-1A-1K and TAR04-2A-1K) retrieved from the deeper central area in the spring of 2004 with a modified Kullenberg piston coring platform from the Limnological Research Center (LRC), University of Minnesota (USA). Physical properties (including magnetic susceptibility, GRA bulk density and P-wave velocity) were measured every cm with a Bartington magnetic susceptibility bridge at the LRC. Results are reported as instrumental units. Once the cores were split in two halves, they were imaged with a DMT Core Scanner and analysed for magnetic susceptibility every $0.5 \mathrm{~cm}$ with a pointer sensor. From the colour pictures, the Lightness $\left(\mathrm{L}^{*}\right)$ parameter was obtained following the LRC procedures (http://lrc.geo.umn.edu). Sedimentary facies were defined by macroscopic visual description including colour, grain-size, sedimentary 
structures, fossil content, and by microscopic smear slide observations (Schnurrenberger et al. 2003).

In addition to standard core logging methods, we applied a method of geochemical core logging: the ITRAX XRF core scanner. XRF data used in this study were produced by the ITRAX XRF core scanner from the Large Lakes Observatory (Duluth) of the University of Minnesota (USA) using 30 seconds count time, $30 \mathrm{kV} \mathrm{X-}$ ray voltage and an X-ray current of $20 \mathrm{~mA}$ to obtain significant data of the following elements: $\mathrm{Si}, \mathrm{K}, \mathrm{Ca}, \mathrm{Ti}, \mathrm{V}, \mathrm{Cr}, \mathrm{Mn}, \mathrm{Fe}, \mathrm{Rb}, \mathrm{Sr}, \mathrm{Y}, \mathrm{Zr}, \mathrm{Ba}, \mathrm{Pb}$. The resulting data are element peak areas. Element concentrations are not directly available by the XRF measurements and the installed processing software, but the obtained values can be used as relative concentrations. X-ray radiographs were obtained with the same ITRAX core scanner using $60 \mathrm{kV}$ X-ray voltage and $60 \mathrm{~mA}$ of current intensity. Statistical treatment of XRF data was carried out using the Multi-Variate Statistical Package (MVSP 3.1).

The TAR04-1A-1K core was sampled every $5 \mathrm{~cm}$ for organic matter and carbonate content. Total carbon, total sulfur and organic carbon contents were analyzed with a LECO SC 144DR elemental analyzer at the Pyrenean Institute of Ecology CSIC, in Zaragoza, Spain. Additionally, those samples were analyzed by a VARIO MAX CN elemental analyzer for the total nitrogen content. Pollen grains and spores were extracted in the laboratory by the classic chemical method (Moore et al. 19781991) modified using Thoulet dense liquid (2.0) for palynomorphes flotation and Lycopodium clavatum spore tablets to calculate the pollen concentration. Previous pollen samples from the short Core B published elsewhere (Valero-Garcés et al. in press) were also considered here for the palaeovegetation reconstruction.

The chronology for the lake sequence is constrained by 9 AMS ${ }^{14} \mathrm{C}$ dates from several cores obtained from Taravilla Lake (Table 1 and Figure 2). To construct the age 
model, previously published results from the ${ }^{210} \mathrm{~Pb}$ and ${ }^{137} \mathrm{Cs}$ analyses were also considered (Valero-Garcés et al. in press).

\section{Results}

Facies description and lithological units

The Taravilla sedimentary record is composed of decimetre-bedded, massive to faintly laminated, brownish gray, carbonate sediments with variable amount of organic remains and several intercalated sandy layers. Five main sedimentary facies have been identified after integration of visual description, microscopic observations and sediment composition (Table 2). Facies 1, 2 and 3 are massive to faintly laminated carbonate mud, silt and sand with variable organic matter, carbonate and silicate contents. Dark colored, massive sands (Facies 1) represent deposition during periods of exceptionally high energy. Facies 2 are interpreted as coarser deposition during episodes of allocthonous material supply reaching the centre of the lake. Massive, lighter grey silt and mud (Facies 3) represent deposition during periods of less strong alluvial influence, but still open water circulation in the lake. These facies are arranged in decimetre to meter-thick fining upward sequences (Figure 2). Facies 4 are $\mathrm{cm}$-thick layers with high organic matter content, mainly derived from fragments of macrophytes. Finally, Facies 5 is composed of finely laminated, light grey, fine carbonate silt and mud. They have relatively lower carbonate content and sandy layers are absent. Facies 5 represents deposition in a lower energy environment, with less alluvial influence, as denoted by the lamination and lack of sandy intervals. This facies only appears in the lowest interval, alternating with cm-to dm thick layers of Facies 2. 
The Taravilla Lake record has been divided in four sedimentological units mainly based on the sedimentological description (Figure 2). Lithological correlation between $1 \mathrm{~A}$ and $2 \mathrm{~A}$ cores was based on the sedimentological description, the Lightness and the magnetic susceptibility values (Figure 2). This correlation allows us to cover the whole sedimentary sequence, using TAR04-2A-1K for the upper part (Unit 1) and TAR04-1A-1K for the lower interval (Units 2, 3 and 4). Furthermore, the correlation with the uppermost unit of short cores A2 and B, mainly based on lithological properties, presence of sandy layers and organic carbon content (Figure 2) provides two additional dates for the age model (Table 1). Up to 5 sandy and organic-rich layers (marked from 1 to 5 in Figure 2) were used to correlate short cores A2 and B with long cores $1 \mathrm{~A}$ and $2 \mathrm{~A}$.

The basal Unit 4 is composed of laminated sediments alternating Facies 5 and Facies 2. Unit 3 is characterized by the dominance of darker carbonate silts in thick layers (Facies 2) alternating with some organic-rich layers (Facies 4). Unit 2 encompasses a thick fining upward sequence composed of Facies 1, 2 and 3 (from bottom to top). The top Unit 1 is characterized by an alternation of dm-thick layers of Facies 2 and 3.

Organic matter content and TOC/TN ratio

The TOC content of the Taravilla sediments (core TAR04-1A) is about $4 \%$ in average although it ranges from 2 to $18 \%$ (Figure 2). Unit 1 is characterized by TOC from 2 to $6 \%$, lower values generally associated with Facies 3 . Unit 2 average TOC value is 5\%, peaking up to $9 \%$ in two organic matter-rich layers (Facies 4). Unit 3 has the highest TOC percentages, averaging $7 \%$ and reaching the maximum of $18 \%$ in one of the 
macrophyte-rich layers. Unit 4 shows the lowest average values of TOC (1\%) with only one abrupt increase, at the sampling resolution, related to organic-rich Facies 4 (Figure 2).

Additionally, the TOC/TN ratio clearly indicates that most of the organic matter in the core is of terrestrial origin (Meyers and Lallier-Vergès 1999). Thus, Units 2 and 3 have an averaged ratio of 15, increasing up to 30 in Facies 4 layers (Figure 2). However, Unit 4 with TOC/TN ratio values below 10 indicate a major contribution of lacustrine algal organic matter, coherent with their deposition in a lower energy environment, with less alluvial influence.

Physical properties: colour and magnetic susceptibility

Magnetic susceptibility of Taravilla sediments is highly variable (0 to $20 \mathrm{SI}$ ) (Figure 2). Low values are related to sandy layers and to high organic matter contents in Facies 1 and 4. On the contrary, Facies 2, 3 and 5 - silts with lower TOC percentages - show higher magnetic susceptibility values. Facies 1, due to its sandy character and the dominance of carbonates (TIC $>8 \%$ ) has extremely low magnetic susceptibility values. Both GEOTEK measurements (loop sensor in closed cores and pointer sensor in open cores) are similar (Figure 2).

Colour parameters are useful tools to infer the carbonate and/or the iron oxides contents in the sediments (Blum 1997). In this case, the $\mathrm{L}^{*}$ record inversely correlates with the TOC percentage but provides a much higher resolution (Figure 2). Thus, lower lightness values are observed in Unit 3 while higher values are in Units 1 and 4 . The distinctive thick sequence of Unit 2 has constant values of TOC and Lightness (Figure 
2). The noisy character of Lightness along Unit 2 is related to the presence of small holes and cracks on the surface of the coarse sandy sediment.

The sedimentological description together with the organic content and the physical properties (magnetic susceptibility and colour) allow the identification of 18 detrital layers along Unit 1 (marked by letters from $A$ to $R$ in Figure 2). Unit 2 represents a thick fining upward layer composed of Facies 1, 2 and 3 (from bottom to top). However, in order to discriminate the input of terrigenous material to Taravilla Lake in the lower units (Units 3 and 4), additional characteristics are needed since the sedimentological criteria are not so evident (e.g. lack of coarse sandy layers, lack of organic matter-rich layers).

Geochemical data obtained by the ITRAX XRF Core Scanner

The ITRAX XRF Core Scanner provided a high-resolution record (every $2 \mathrm{~mm}$ ) of geochemical variations and the x-ray radiograph for the lower $3 \mathrm{~m}$ of Taravilla composite sequence (from 3.2 to $6.2 \mathrm{~m}$ depth, Figure 3 ). The density contrasts shown by the radiograph clearly indicate the presence of organic-rich layers (Facies 4) by lighter colours (lighter sediments) and of clay-rich facies by darker layers (denser sediments). The down-core profiles of heavy and light elements noticeably delineated the different units already described by the sedimentological analyses and the physical properties. Broadly, we observe a reverse pattern among $\mathrm{Ca}$ and the other elements along Unit 2 (Figure 3). Thus, Ca profile peaks at the base of the unit and decreases upwards (following the $\mathrm{L}^{*}$ values) while $\mathrm{Mn}, \mathrm{Ti}, \mathrm{K}, \mathrm{Si}$ and $\mathrm{Fe}$ display the opposite trend (coherent with the MS record). Similar behaviour is observed along Unit 3: higher Ca values are attained at lighter layers (marked from $A$ to $F$ by the increase in lightness 
values) while the other elements increase at darker layers, probably related to the presence of finer siliciclastic particles (clay minerals, oxides). Similarly to Unit 2, but at a smaller scale, the higher Ca values indicate the base of an upward fining sequence (see arrows in Figure 3). The two organic-rich layers (Facies 4) observed in Unit 3 are characterized by the simultaneous decrease of all the elements and the bright colours in the radiograph (Figure 3). These layers usually appear at the base of the upward fining sequences marking the onset of an allocthonous layer. Unfortunately, there are not such organic-rich layers in Unit 4 to clearly identify the episodic entrance of detrital material in Taravilla Lake. Thus, statistical analyses were performed to objectively describe the similarities and differences between the elements in order to better identify the presence of terrigenous layers.

\section{Correlation analyses}

Although the three units discussed above (Unit 2, 3 and 4) can be clearly seen by the down-core elemental variation, several patterns arise when the correlation coefficients are examined more closely (Table 3). First, it is evident the opposite behaviour of Ca, an element that has significant but negative correlation with all the other elements. Manganese is the only one that does not show any correlation with the other elements, pointing to a different origin of this element, likely related to redox variations (Aguilar and Nealson 1998). Although the other elements are well correlated among them, two

different groups can be observed: (1) Si, K, Ti, Sr, Zr and (2) V, Cr, Fe, Pb. Only three elements ( $\mathrm{Y}, \mathrm{Rb}$ and $\mathrm{Ba})$ do not clearly match with any of those two groups. 
Principal Component Analysis (PCA) was carried out using an elemental dataset (14 variables and 1686 cases) to objectively describe the main variance of the dataset by only a few factors and in order to confirm the previously observed patterns by the correlation analyses. The first two eigenvectors accounted for $76.83 \%$ of the total variance (Table 3a). The first eigenvector represented $60.8 \%$ of the total variance, and this eigenvector was controlled mainly by the $\mathrm{Ca}$ at the negative end and the other light and heavy elements at the positive end (Figure 4, Table 3b). On the other hand, the second eigenvector accounted for $16.03 \%$ of the total variance, and was controlled by the presence of $\mathrm{V}, \mathrm{Cr}, \mathrm{Mn}, \mathrm{Fe}, \mathrm{Ba}$ and $\mathrm{Pb}$ at the positive end and by $\mathrm{Si}, \mathrm{K}, \mathrm{Ti}, \mathrm{Rb}, \mathrm{Sr}, \mathrm{Y}$ and $\mathrm{Zr}$ at its negative end (Figure 4, Table $3 \mathrm{~b}$ ). The role of $\mathrm{Ca}$ in this second factor is not important (a factor loading of -0.009). The other eigenvectors defined by the PCA analysis (up to 14) were not taken into account to interpret the geochemical variability given that they accounted for very low percentages of the total variance (Table 3a).

The PCA analyses confirm (i) a clear opposite pattern among $\mathrm{Ca}$ and the rest of the elements and (ii) that the elements are secondarily grouped by their detrital origin $(\mathrm{Si}, \mathrm{K}, \mathrm{Ti}, \mathrm{Rb}, \mathrm{Sr}, \mathrm{Y}$ ) or their relation to redox processes $(\mathrm{V}, \mathrm{Cr}, \mathrm{Mn}, \mathrm{Fe}, \mathrm{Ba}, \mathrm{Pb}$ ) (Eusterhues et al. 2005; Hamilton-Taylor et al. 2005; Morford and Emerson 1999). This result provides an additional criteria for the reconstruction of allocthonous material supply to Taravilla Lake, particularly along Unit 4 where the almost absence of sandy layers prevents a clear identification from the study of sedimentological and physical properties.

Thus, in Figure 3 we represent the location of every sample with respect to the new axis defined by the PCA. The value for every sample indicates a specific position with respect to the carbonate and siliciclastic inputs, respectively. All samples located at 
the negative end of the first eigenvector (low values of the x-coordinate, Figure 4) are composed of carbonate-rich material. The same is true for those samples located at the positive end of the second eigenvector, but with respect to siliciclastic material (Figure 4). Hence, the plot of the $\mathrm{x}$ - and $\mathrm{y}$-coordinates of every sample with respect to their core depth will allow us to qualitatively reconstruct the evolution of the input of the carbonatic material (eigenvector 1) and that of siliciclastic input (eigenvector 2) (Figure 4). From this comparison appears evident that only the intervals where both eigenvectors vary in the same direction (that is, more carbonate and more siliciclastic supply) will be alloctonous supplies to the lake. These intervals are well correlated with Facies 2 in Unit 4 and they are usually characterized by increase in both eigenvectors at the base of the sequence and a continuous decrease towards the top, similarly to the thicker sequences identified in the uppermost units. The four identified sequences in Unit 4 following these geochemical criteria are marked (A to D) in Figure 3.

Pollen results

The pollen content of the Taravilla Lake sequence is highly variable reflecting the alternation of lake sediments facies and intercalated terrigenous layers, where both the palynological content and the preservation are low. Consequently, there are no pollen results for some intervals of the sequence (Figure 5). Nevertheless, the composite sequence constructed with Unit 4 and 3 from core TAR04-1A and Unit 1 from Core B allow the reconstruction of the vegetation history and provide some clues of the influence of global climatic events and anthropogenic impact in the lake and watershed dynamics. During the last 2000 years, the regional vegetation reflects a similar landscape as the current pine-dominated forest. Through the sequence, pine is the 
dominant arboreal taxa and the evolution is characterized by fluctuations in (i) mesothermophytes (deciduous trees - deciduous Quercus, Corylus, Betula, Salix, Ulmus, Tilia, Populus, Fraxinus and Juglans - and Mediterranean-type component evergreen Quercus, Olea, Phillyrea, Viburnum, Lamiaceae, Ephedra fragilis type, Genisteae, Ericaceae, Cistus, Rhamnus, Myrtus and Thymelaea -), (ii) anthropogenic indicators and (iii) aquatic plants (Apiaceae, Ranunculaceae, Thalictrum, Cyperaceae, Typha, Potamogeton, Myriophyllum and Nuphar). Fluctuations of these three groups define the main trends. Pollen zones are indicated by letters (from E to A) in Figure 5.

The base of the sedimentary Unit 4 comprises the pollen zone "E" $(605-585 \mathrm{~cm}$ depth) and reflects an open landscape very influenced by anthropogenic activities. The forest formation was composed by junipers, some mesophytes, a small quantity of pines and an important Mediterranean component with some Buxus and Tamarix around the lake (Figure 5). Aquatics percentages are significant and also show high taxa diversity; Myriophyllum reaches its maximum, suggesting a stable lake water level. This is the most open landscape from the whole sequence: higher percentages of Buxus, Fabaceae and Rosaceae point to a shrub-dominated landscape with reduced arboreal presence (only some conifers and deciduous trees). Furthermore, this is the interval with the maximum percentages of cereal and "anthropogenic" plants associated to crops (Cichorioideae, Carduae, Asteroideae, Centaurea, Artemisia, Caryophyllaceae, Plantago, Rumex, Brassicaceae, Urticaceae, Geraniaceae and Malvaceae). The high percentage of aquatics and the relative abundance of deciduous trees, suggest a quite humid and warm environment. The reduced percentage of arboreal pollen could be related to the regional land use for agriculture practices and/or pastoralism during this period. 
The pollen zone " $\mathrm{D}$ ", includes the uppermost interval of the sedimentary Unit 4 (585-475 cm depth), and it is characterized by the gradual increase of pine and decrease of "anthropogenic" plants that finally lead to the almost disappearance of the cereal at the top of the unit (Figure 5). Although with some fluctuations, aquatics and mesophytes percentages remain with similar proportions pointing to mild temperatures and more or less wet conditions. The increase of pine percentages while decreasing agriculture and "anthropic" herbs could be related to a change in land use. A relatively weak anthropogenic pressure is proposed to explain the vegetation cover observed for the upper interval of this pollen zone. This general trend is interrupted by one terrigenous layer at $505 \mathrm{~cm}$, where an increase in pine and a decrease in the other taxa are observed.

Only one pollen sample in Unit 3 (at $454 \mathrm{~cm}$ ) had enough pollen grains to be statistically significant (pollen zone "C", Figure 5). Although most of the grains are broken and in general badly preserved, this sample provides some qualitative information (e.g. pine was the dominant taxa). Additionally, some Tertiary pollen grains were observed pointing to the presence of older material transported to Taravilla Lake during the identified terrigenous events. Besides the Pinus grains (that is mainly Pinus nigra-sylvestris type, usually related to colder conditions), some mesophytes, aquatics and shrubs also occur, although in lower percentages than in pollen zone "D" (Figure 5). The almost absence of "anthropogenic" herbs and the high percentages of Pinus, point to a decrease in human activities in this area during the sedimentary Unit 3 and no deforestation practices. However, it is unclear if this apparent Pinus maximum of the sedimentary Unit 3 is related to a colder climate or to a differential preservation of pollen grains during transport. 
No pollen samples were prepared along the sedimentary Unit 2 since this sedimentological unit corresponds to a thick terrigenous layer in the Taravilla sedimentary sequence where pollen grains may not reflect the vegetation formations, as occurred in other layers. Along the sedimentary Unit 1, two different trends are observed (Figure 5). The first one is the pollen zone "B", from the base to the $73 \mathrm{~cm}$ depth (equivalent to $93 \mathrm{~cm}$ depth in the composite sequence), and probably represents a similar landscape than along Unit 3 . That interval is characterized by dominant pine and very few anthropogenic herbs. Aquatic plants have a modest presence. The pollen zone "A" includes the uppermost $70 \mathrm{~cm}$ and represent an important change in the vegetation cover with a rapid increase in aquatic taxa, more plants related to agricultural practices (although less important than at the base of the sequence) and a higher diversity in the vegetation cover. An increase in temperature (decrease in pines and expansion of the Mediterranean-type component) and humidity (Mesophytes recuperation) is likely the cause for these changes (Valero-Garcés et al. in press).

\section{Discussion}

The results presented here allow us to identify the main characteristics of the terrigenous events throughout the Taravilla Lake record. Thus, the sedimentary signal for these deposits consists on (i) massive to faintly banded layers, usually organized in fining upward sequences; (ii) high organic matter content and high TOC/TN ratio, mainly at the base of the sequences; (iii) low magnetic susceptibility and lightness values and (iv) simultaneous increase of carbonate and siliciclastic inputs indicated by the PCA axis. In summary, both Facies 1 and 2 are mostly composed of allochtonous supply to the basin and they are only different in terms of grain-size. Facies 4 are also 
associated to alloctonous inputs, mainly terrestrial plants. Both Facies 3 (massive to faintly banded) and 5 (laminated) would correspond to periods of less strong alluvial influence.

Applying the identification criteria exposed above, we identified up to 4 terrigenous layers along Unit 4; 6 layers along Unit 3; 1 layer along Unit 2 (Figure 3) and 18 along Unit 1 (Facies 2 in Figure 2). Sedimentological, geochemical and compositional evidences indicate interruption of relatively quiet-water lacustrine deposition by episodic terrestrial sediment influxes perhaps carried to the centre of the pond by density currents. The mechanisms to repeatedly allow sediment transport to Taravilla Lake must be discussed.

Origin and forcing mechanisms of terrigenous layers in the Taravilla record

We consider three possible forcings behind the presence of terrigenous layers in the Taravilla record: (1) earthquakes triggering mass movement, (2) removal of vegetation by blight or fire, and (3) large hydrologic events (episodic extreme floods) caused by storms or snow melt. Although extentional neotectonics is still active in the Iberian range (Simón 1989), we may discount earthquakes as the main mechanism to produce the terrigenous layers in Taravilla since none of the more important historical earthquakes recorded in the Iberian Peninsula during the last 1000 years occurred in this area (http://www.ign.es). Additionally, the fining upward textures described in the Taravilla record does not coincide to the more massive and unsorted sediments expected if they were related to earthquake activity. Another sedimentary characteristic that evidences the presence of earthquake activity is the presence of slumps or homogenite layers that are not found in this record (Leroy et al. 2002). 
Discerning among human activity and climate forcings on the vegetation changes is always a difficult task (González-Sampériz et al. in press). Unexpectedly, the maximum in human activities was reached during the oldest part of the Taravilla Lake sequence (Unit 4, Figure 5) and decreased upwards with minimum activity during the middle part of the sequence (Units 3 and 2). Human activities are marked by the percentages of crops and anthropics (Figure 5) that could be related to agricultural land use. Thus, pollen results indicate that the most intense human influence on the vegetation cover in this area happened at the beginning of the record, where terrigenous layers are very scarce and the sedimentation indicates a quieter lacustrine environment. Thus, significant removal of vegetation by human fires or deforestation practices is discarded as the main mechanism behind the observed increased in terrigenous layers in Taravilla Lake sediments, at least for Units 3, 2 and the base of Unit 1. Human activities seem to be important again during deposition of the upper meter of the composite sequence where a decrease in Pinus and an increase in thermophilous-Mediterranean taxa and anthropic herbs are observed.

Previous studies have considered that the hydrological response of the different rivers and drainage basins during the last millennia was influenced by both climate variability and human activity (Riera et al. 2004; Valero-Garcés et al. 2006). However, in the Tagus River basin, the generation of extreme flood layers is shown to be caused by an excess of precipitation with a minor/local role played by antropogenic processes, such as deforestation or soil uses (Benito 2006). The role of such physical factors (amount of vegetation cover, type of soil, soil humidity previous to the precipitation event), is thus not influencing the frequency of the paleofloods but modulating their intensity (Benito et al. 1998). Therefore, the frequency of paleofloods events is directly 
related to the atmospheric circulation patterns that are able to generate intense precipitation in the Taravilla catchment area.

Consequently, the most likely cause for the deposition of coarser, terrestrial sediment layers is increased runoff triggered by extreme hydrologic events, such as storms which increase rates of hillslope erosion, stream-channel scouring, and pondmarginal sediment reworking, as pointed by other authors in similar environments (Brown et al. 2000; Noren et al. 2002). Changes in the amount, frequency and intensity of precipitation have an effect on the magnitude and timing of runoff and the intensity of floods, even in a small catchment area as this one from Taravilla Lake. Specifically, we suggest that terrestrial sediment stored in the watershed and at the pond margins is transported toward the centre during storm events that significantly increase stream discharge and erosion. The timing of these flood layers will give us a better understanding of the climate processes that forced them and will allow comparing our results with other paleoflood reconstructions in the Tagus River.

Chronology of the Taravilla sequence and paleoflood timing

The chronological model for the composite sequence presented here is improved from the previously published (Valero-Garcés et al. in press) with more radiocarbon dates in the TAR04-1K-1A core (Table 1, Figure 6). Additionally, accurate lithological correlation allowed the use of the dates from short cores A2 and B (Figure 2). The ${ }^{210} \mathrm{~Pb}$ results for the uppermost part of the sequence were used to constrain the chronology (Valero-Garcés et al. in press). Several ${ }^{14} \mathrm{C}$ samples were not included in the chronological model. Two of the three rejected samples provided ages older than expected (Figure 6). The reason for this, as observed in other similar studies (Nesje et 
al. 2001), is probably that during a flood event, older organic material is eroded and transported into the lake, thereby giving older ages than the actual flood event. In fact, some Tertiary pollen grains observed in samples from Unit 3 supports this conclusion. The young age of the third rejected sample, at $260 \mathrm{~cm}\left(340 \pm 30{ }^{14} \mathrm{C} \mathrm{yr} \mathrm{BP}\right)$, is likely caused by contamination with younger carbon.

The remaining samples have been converted into calendar ages by the CALIB 5.0.2 software that uses the most updated data set (the INTCAL04 curve; (Reimer et al. 2004). The mid-point of $95.4 \%$ ( $2 \sigma$ probability interval) was selected for these dates resulting in errors of $\pm 50 \mathrm{yr}$ (in average) in the obtained calendar ages (Table 1). Finally, an age-depth model was constructed based on interpolated ages between adjacent pairs of dates (Figure 6a). Rejected dates are also plotted as open triangles. The linear sedimentation rate is highly variable, ranging from $0.12 \mathrm{~cm} / \mathrm{yr}$ during the IV to XII centuries (Unit 4, laminated interval) to $0.82 \mathrm{~cm} / \mathrm{yr}$ during the last 600 years corresponding to the upper $4.7 \mathrm{~m}$ of the sequence (Figure 6a). The fact that two of the dated samples only separated by $10 \mathrm{~cm}$ have 300 years of difference suggests the presence of an erosive hiatus just after Unit 4. This is coherent with the abrupt change observed in the sedimentological features (Figure 2) and the erosive character inherent to the deposition of Facies 2. Therefore, sediments from 1100 to 1400 cal yr AD are missing.

In order to construct a chronological model, we must take into account that flood events may occur in very short time, maybe in several hours. Thus, because flood layers do not represent significant time within the chronology, but do represent a significant thickness, their thickness was removed prior to age modelling, following the procedure described by (Bøe et al. 2006). Thus, once detected the flood layers following the criteria exposed above, we subtract them from the model and apply a constant 
sedimentation rate among the upper and lower dates to obtain the chronological model (Figure 6b). After doing that, the linear sedimentation rate obtained for the sequence without the flood layers is constant and similar to the one previously obtained for Unit 4 $(0.14 \mathrm{~cm} / \mathrm{yr})$ thus confirming the interpretation of quiet-water lacustrine deposition interrupted by episodic terrestrial sediment influxes. Finally, we include again the position of flood layers considering them as instantaneous events (Figure 6c). This approach allows us to obtain a more realistic age model for this particular environment.

Comparison with other records

The Little Ice Age and the Medieval Warm Period from Taravilla Lake record.

A wide range of climate proxies measured throughout the Globe indicate that temperatures were colder than present during the LIA (Abrantes et al. 2005; Bond et al. 1999; Bradley and Jones 1993). Additionally, several records show that the LIA was also characterized by less precipitation (Desprat et al. 2003; Haug et al. 2003; ValeroGarcés et al. 2003; Verschuren et al. 2000) although some other studies point to a more complex pattern alternating wetter and dryer intervals (Rumsby and Macklin 1996). In spite of the timing of this event is not totally clear, we consider here from 1300 to 1900 AD following (Jones et al. 2001). This cold period was preceded by warmer temperatures in medieval times. Although less clearly defined and dated in a lower number of sites, the MWP is considered to have occurred between 800 and 1300 AD (Jones et al. 2001). Both the LIA and the MWP are considered to be related to variations in solar activity, although this link is still controversial (Bard et al. 2000). 
In Europe, the Little Ice Age was characterized by a high hydrological variance with frequent floods and droughts. Fluvial records in many river basins in NW and Central Europe indicate lower rates of fluvial activity than periods before or after (e. g. (Rumsby and Macklin 1996), whereas alluvial response in the many Mediterranean catchments shows high sediment influx and valley sedimentation (Gregory et al. 2006). At this time scale, it is evident from the Tagus Basin study that paleofloods were more frequent during the LIA than during the MWP (Benito et al. 2004; Benito et al. 2003a; Benito et al. 1996).

In Figure 7, we have plotted several climate and solar reconstructions together with Taravilla paleoflood evidences in order to compare them and interpret the observed pattern throughout the LIA and the MWP intervals. Thus, the paleoflood reconstruction from the Taravilla sediments is shown as red lines (Figure 7E) and a 25-years-moving average (Figure 7F). These results show two different responses of the paleoflood frequency for the last millennia: during the MWP there is almost no evidence of flood deposits in the lake while during the LIA presence of flood layers is evident. As we can observe in Figure 6, in terms of sedimentary units and considering the possible hiatus between Units 4 and 3, the change from the MWP to the LIA, correspond to the transition among Unit 4 (lower energy environment, with less alluvial influence, and more warmer conditions according to palynological data) and Unit 3 (abundant fining upward sequences signalling flood deposits and colder climate suggested by Pinus nigra-sylvestris type as the main pollen taxum preserved). Therefore, the Taravilla record strongly support previous evidences from the Tagus Basin of higher flood frequency during the LIA (Benito et al. 2003a). 
To discern if there is any relation of increased frequency of flood events with solar activity variability, sun spot number, northern hemisphere temperatures or NAO variability, a closer look is necessary. Figure 7 shows the correlation among sun spot frequency (Figure 7A), that is, maximums in solar activity (Figure 7B) indicated by blue bands, with the Tagus Basin paleoflood reconstruction (Figure 7G) as was proposed by (Vaquero 2004). Only the Last Medieval maximum does not correspond to any paleoflood increase. This similarity was interpreted to reflect the influence of the NAO in the precipitation patterns of the Iberian Peninsula. According to (Kirov and Georgieva 2002), if the secular solar activity is high, the 'smoothed' NAO index is low. If this 'smoothed' NAO index is low, then the precipitation over the Iberian Peninsula increase and the probability of floods in the Tagus Basin should increase consequently. However, the 'smoothed' NAO index (Cook et al. 2002), plotted in Figure 7D, compared to solar variability or to northern hemisphere temperatures (Figure 7C; (Mann and Jones 2003)) does not present a systematic correlation (i.e. not all the low NAO periods correspond to high secular solar activity).

From the Taravilla record we have represented versus age the reconstruction of paleofloods (red lines) (Figure 7E) together with their average every 25 years (Figure 7F). Bands numbered from 1 to 7 indicate the periods with higher flood frequency. Flood magnitude and frequency vary among drainage basins depending upon the network variability in scale and morphometry but mainly on the weather systems that produce flood events (Benito et al. 1996). Thus, the paleoflood reconstruction from Taravilla Lake, located in the Tagus headwaters, has been mainly compared to the results from the compilation of palaeohydrological data generated in the Tagus drainage basin during the last millennium (Benito et al. 2003a). However, due to differences in 
the spatial scale considered in Taravilla and in the Tagus drainage area (eg. $5 \mathrm{~km}^{2}$ vs $52,000 \mathrm{~km}^{2}$ ), together with differences in the synoptic conditions that lead to rainfall (eg. convective storms in autumn in Taravilla), we are not expecting to observe a good overlap of specific flood events but a synchrony in the main periods of higher paleoflood frequency. Accordingly, five periods of concentrated flood events were identified from the Tagus Basin (Benito et al. 2003a): 1200-1230 yr AD; 1560-1620 yr AD; 1700-1720 yr AD; 1740-1810 yr AD; 1860-2000 yr AD (Figure 7G). Those periods are indicated in Figure $7 \mathrm{G}$ by bands numbered from $\mathrm{I}$ to $\mathrm{V}$ and compared with the timing of the Taravilla paleofloods. The correlation is evident mostly in the upper part of the record corresponding to the Little Ice Age. The oldest group of Tagus paleoflood events (band I) does not have a correspondent in Taravilla because it lies in the sedimentary hiatus. After that, once the frequency of floods from the Tagus Basin starts to increase at about $1420 \mathrm{yr}$ AD a similar behaviour is observed in the Taravilla record. Thus, bands 2, 3 and 4 in Taravilla correlate with band II in (Benito et al. 2003a) and the two previous small peaks (Figure 7G). No correlation is observed during the Maunder Minimum when a maximum in the frequency of paleofloods in the Tagus Basin is detected (band III) but not in Taravilla Lake sediments. Finally, bands IV and V in (Benito et al. 2003a) would correspond to the last three paleoflood events (bands 5, 6 and 7) in Taravilla sequence, although the correlation is not perfect. For the observed recent increase in flood frequency in both records, we must consider the preservation potential of the flood layers, usually higher for more recent sediments.

All these periods of maximum paleoflood concentration coincide with increases in the number of sun spots (Vaquero et al. 2002) and, thus, in solar activity (Bard et al. 2000). Even the oldest group of flood layers from Taravilla Lake, that did not show a correspondence with any of the paleoflood intervals from (Benito et al. 2003a), is 
related to an interval with higher sun spot numbers (marked by a dashed square in Figure 7). The only exception to this pattern of maximum in solar activity increase in flood frequency is period III in the Tagus Basin that coincides with a minimum in solar irradiance, the Maunder Minimum. Thus, solar forcing seems not to be influencing precipitation at that interval.

Focusing in the coastal Mediterranean area of Spain, (Barriendos and MartínVide 1998) describe three flood periods for the last 700 years $(1570-1630 ; 1760-1800$ and 1830-1870) and three drought periods (1361-1390; 1511-1540; 1880-1950) (Figure $7 \mathrm{H}$, green and orange bands). Although this record also suggests higher flood events during the LIA, the fact that only covers the last 700 years prevents any further comparison in terms of LIA $v s$ MWP. In any case, the different weather patterns of the coastal Mediterranean area avoid the attempt of correlation with the Taravilla Lake or the Tagus Basin paleoflood reconstructions. This is possible the cause of not observing a good correspondence between the (Barriendos and Martín-Vide 1998) data (Figure 7H) and solar activity (Figure 7B). Some previous studies also indicate that the influence of NAO is lower in that area of Spain (Rodò et al. 1997; Trigo et al. 2004) thus discarding the climate mechanism suggested for the Taravilla Lake and Tagus Basin as the main forcing of paleoflood frequency for the Mediterranean region. On the contrary, the NAO mechanism that controls most part of present-day winter precipitation in the Taravilla catchment (see Figure 1D) seems to also have an influence on the frequency of paleofloods during the LIA. Comparing the smooth NAO record (25-years-moving average, Figure 7D) with the frequency of paleofloods in Taravilla (25-years-moving average, Figure 7F) a similar pattern can be detected, indicating an increase in the flood frequency when NAO is more negative. However, this correlation 
among the NAO and the paleoflood frequency requires other records with detailed chronologies to be better constrained.

\section{Conclusions}

The combination of sedimentological, physical, geochemical and palynological criteria in the available cores from Taravilla Lake allows the identification of several allocthonous terrigenous layers in the sedimentary sequence that are the consequence of extreme rainfall events during the last 2000 years. Thus, the sedimentary signal for these deposits consists on massive to faintly banded layers organized in fining upward sequences; high organic matter content at the base of the sequences; low magnetic susceptibility and lightness values and simultaneous increase of carbonate and siliciclastic inputs. High-resolution analyses of physical properties and geochemical composition by means of a XRF core scanner, together with a statistical treatment of the database, provides additional criteria to identify the paleoflood layers along the whole sequence. Human impact on the surrounding vegetation by means of fires or massive deforestation is discarded as the main mechanism on producing the material for these layers since it was negligible at the times of maxima flood generation.

The production of extreme flow events in the Taravilla Lake watershed is minima during the MWP while the onset of the LIA is characterized by an increase in the frequency of such events, coherently with a previous paleoflood reconstruction study on the Tagus River basin (Benito et al. 2003a). Close comparison among the Taravilla paleoflood events and the Tagus River reconstruction indicates that, in spite of some minor differences on the timing between both records, the main periods with more frequent extreme events are well reproduced. The NAO variability at a decadal-scale, 
modulated by fluctuation on solar radiation at a centennial-scale, are the two proposed forcing mechanisms to generate in the Taravilla Lake catchment the amount of rainfall necessary to produce an increase in the supply of allocthonous sediments to the lake basin.

\section{Acknowledgments}

Financial support for research at Taravilla Lake was provided by the Spanish InterMinistry Commission of Science and Technology (CICYT), through the projects LIMNOCLIBER (REN2003-09130-C02-02) and IBERLIMNO (CGL2005-20236E/CLI). A. Moreno acknowledges the funding from the European Commission's Sixth Framework Program (Marie Curie Outgoing International Fellowships, proposal 021673-IBERABRUPT). We are indebt to Doug Schnurrenberger, Anders Noren and Mark Shapley (LRC, University of Minnesota) for the 2004 coring expedition, Erik Brown (LLO, Duluth, University of Minnesota) for his technical help on the XRF core scanner and the Spanish National Meteorological Institute (INM) for providing the climatological data. We thank Gerardo Benito for his comments on an earlier version of the manuscript and the Tagus River paleoflood reconstruction data. 
Table 1 Radiocarbon dating of Taravilla cores analyzed at Arizona laboratory (AA) and Poznan Radiocarbon Laboratory, Poland (Poz-). Samples in italics were discarded (reversals or incoherent with previously studied cores). See text for explanation and calibration procedures

\begin{tabular}{|c|c|c|c|c|c|c|c|c|}
\hline \multirow{2}{*}{ Unit } & \multirow{2}{*}{ Sediment sample } & \multirow{2}{*}{ Lab code } & \multirow{2}{*}{$\begin{array}{c}\text { Depth } \\
\text { (seq. } \\
\text { comp) }\end{array}$} & \multirow{2}{*}{ Material } & \multirow{2}{*}{$\begin{array}{c}{ }^{14} C \\
y r \\
B P\end{array}$} & \multirow{2}{*}{$\begin{array}{c}\text { Age } \\
\text { error } \\
(y r)\end{array}$} & \multicolumn{2}{|c|}{ Calibrated age $(2 \sigma)$} \\
\hline & & & & & & & Cal yr BP & Cal yr $A D$ \\
\hline 1 & Core $\mathrm{A} 4, \mathrm{~cm} 70$ & AA48628 & 88 & Wood & 199 & 50 & $59-234$ & $1716-1891$ \\
\hline 1 & Core B, cm 120 & AA48629 & 141 & Wood & 296 & 41 & $286-476$ & $1474-1664$ \\
\hline 1 & TAR04-1A-2,40 & Poz-9892 & 216 & Organic macrorests & 375 & 30 & $435-497$ & $1453-1515$ \\
\hline 3 & TAR04-1A-3, 75 & Poz-13683 & 398 & Bulk sediment & 1215 & 35 & $1059-1189$ & $689-752$ \\
\hline 3 & TAR04-1A-3, 92 & Poz-18437 & 415 & Bulk sediment & 960 & 30 & $795-929$ & $1021-1155$ \\
\hline 3 & TAR04-1A-3, 130 & Poz-9809 & 453 & Organic macrorests & 340 & 30 & $311-480$ & $1470-1639$ \\
\hline 3 & TAR04-1A-4, 5 & Poz-18378 & 469 & Bulk sediment & 480 & 30 & $508-529$ & $1421-1442$ \\
\hline 4 & TAR04-1A-4, 15 & Poz-17195 & 479 & Bulk sediment & 940 & 30 & $791-925$ & $1025-1159$ \\
\hline 4 & TAR04-1A-4, 135 & Poz-12366 & 599 & Bulk sediment & 1695 & 30 & $1534-1636$ & $314-416$ \\
\hline
\end{tabular}


Table 2. Sedimentary facies in Taravilla cores.

\section{Facies Description and depositional environment}

Facies 1: Massive, dark $\mathrm{Cm}$ - to dm-thick beds, massive to faintly laminated, fining grey silty-sand to coarse upward textures; abundant plant macrorest. Depositional sand subenvironment: Flood deposits in the inner areas of the lake.

Facies 2: Massive to $\mathrm{Cm}$ - to $\mathrm{dm}$-thick layers, massive, variable amount of carbonate faintly laminated light and organic matter $\begin{array}{ll}\text { grey carbonate silt } & \text { Depositional subenvironment: Deposition } \\ \text { lake during open water circulation periods }\end{array}$

Facies 3: Massive to faintly laminated, dark grey carbonate silt and mud

$\mathrm{Cm}$ to dm-thick layers, faintly laminated, relatively higher organic matter and lower carbonate content. Relatively high magnetic susceptibility.

Depositional subenvironment: Deposition in the middle of the lake during periods of more restricted water circulation.

Facies 4: Gastropod and charophyte-rich coarse silt and mud

$\mathrm{Cm}$ - thick layers with abundant fossils and calcified Chara remains. Depositional subenvironment: Littoral lacustrine

Cm-thick layers, laminated, dominant carbonate Facies 5: Laminated light composition.Relatively low magnetic susceptibility. gray-yellowish silt Depositional subenvironment: middle of the lake, low energy dominant oxic bottom conditions 
Table 3 Correlation coefficients among the elements obtained by the ITRAX XRF Core Scanner. Values in italics are below 0.5 pointing to a lack of correlation among the elements

\begin{tabular}{|c|c|c|c|c|c|c|c|c|c|c|c|c|c|c|}
\hline & $\mathbf{S i}$ & K & $\mathrm{Ca}$ & Ti & V & $\mathrm{Cr}$ & Mn & $\mathbf{F e}$ & $\mathbf{R b}$ & $\mathrm{Sr}$ & Y & $\mathrm{Zr}$ & Ba & $\mathbf{P b}$ \\
\hline $\mathbf{S i}$ & 1.00 & & & & & & & & & & & & & \\
\hline $\mathbf{K}$ & 0.69 & 1.00 & & & & & & & & & & & & \\
\hline $\mathbf{C a}$ & -0.57 & -0.65 & 1.00 & & & & & & & & & & & \\
\hline $\mathbf{T i}$ & 0.78 & 0.79 & -0.83 & 1.00 & & & & & & & & & & \\
\hline $\mathbf{V}$ & 0.47 & 0.54 & -0.73 & 0.75 & 1.00 & & & & & & & & & \\
\hline $\mathbf{C r}$ & 0.48 & 0.57 & -0.73 & 0.78 & 0.87 & 1.00 & & & & & & & & \\
\hline Mn & -0.28 & -0.10 & -0.15 & 0.04 & 0.31 & 0.39 & 1.00 & & & & & & & \\
\hline $\mathbf{F e}$ & 0.26 & 0.53 & -0.62 & 0.66 & 0.73 & 0.79 & 0.45 & 1.00 & & & & & & \\
\hline $\mathbf{R b}$ & 0.67 & 0.87 & -0.85 & 0.91 & 0.76 & 0.79 & 0.09 & 0.68 & 1.00 & & & & & \\
\hline $\mathbf{S r}$ & 0.68 & 0.87 & -0.57 & 0.72 & 0.44 & 0.44 & -0.27 & 0.29 & 0.75 & 1.00 & & & & \\
\hline $\mathbf{Y}$ & 0.56 & 0.50 & -0.77 & 0.73 & 0.62 & 0.62 & -0.01 & 0.35 & 0.71 & 0.54 & 1.00 & & & \\
\hline $\mathbf{Z r}$ & 0.72 & 0.43 & -0.71 & 0.73 & 0.49 & 0.49 & -0.09 & 0.22 & 0.59 & 0.42 & 0.72 & 1.00 & & \\
\hline $\mathbf{B a}$ & 0.55 & 0.45 & -0.72 & 0.70 & 0.76 & 0.85 & 0.21 & 0.57 & 0.70 & 0.42 & 0.69 & 0.59 & 1.00 & \\
\hline $\mathbf{P b}$ & 0.18 & 0.36 & -0.63 & 0.54 & 0.66 & 0.68 & 0.38 & 0.82 & 0.60 & 0.23 & 0.42 & 0.25 & 0.58 & 1.00 \\
\hline
\end{tabular}


Table 3 Principal Component Analyses (PCA). (a) The eigenvalues for the obtained axis are shown. The percentage of the variance explained by every axis is also indicated.

(b) The factorloads for every variable in the two main axis

(a)

\begin{tabular}{|c|c|c|c|c|c|c|c|c|c|c|c|c|c|c|}
\hline & \multicolumn{14}{|c|}{ Axis } \\
\hline & 1 & 2 & 3 & 4 & 5 & 6 & 7 & 8 & 9 & 10 & 11 & 12 & 13 & 14 \\
\hline Eigenvalues & 8.51 & 2.24 & 1.02 & 0.49 & 0.43 & 0.40 & 0.22 & 0.17 & 0.15 & 0.10 & 0.08 & 0.06 & 0.05 & 0.03 \\
\hline Percentage (\%) & 60.8 & 16.03 & 7.34 & 3.53 & 3.06 & 2.86 & 1.58 & 1.22 & 1.12 & 0.74 & 0.58 & 0.47 & 0.39 & 0.21 \\
\hline Cum. Percentage & 60.8 & 76.83 & 84.18 & 87.71 & 90.78 & 93.65 & 95.24 & 96.46 & 97.59 & 98.33 & 98.91 & 99.39 & 99.78 & 100 \\
\hline
\end{tabular}

(b)

\begin{tabular}{lcc} 
& Axis 1 & Axis 2 \\
\hline Si & 0,246 & $-0,351$ \\
$\mathbf{K}$ & 0,269 & $-0,209$ \\
$\mathbf{C a}$ & $-0,309$ & $-0,009$ \\
$\mathbf{T i}$ & 0,325 & $-0,096$ \\
$\mathbf{V}$ & 0,292 & 0,189 \\
$\mathbf{C r}$ & 0,302 & 0,222 \\
$\mathbf{M n}$ & 0,049 & 0,551 \\
$\mathbf{F e}$ & 0,248 & 0,353 \\
$\mathbf{R b}$ & 0,325 & $-0,048$ \\
$\mathrm{Sr}$ & 0,239 & $-0,33$ \\
$\mathbf{Y}$ & 0,269 & $-0,113$ \\
$\mathbf{Z r}$ & 0,239 & $-0,219$ \\
$\mathbf{B a}$ & 0,283 & 0,104 \\
$\mathbf{P b}$ & 0,229 & 0,357
\end{tabular}




\section{Figure captions}

Fig. 1 A. Photograph of the lake, indicating the main inlet and outlet, and location of Taravilla Lake in the Iberian Peninsula map. B. The Taravilla Lake watershed. Isoaltitude lines every $100 \mathrm{~m}$, from $1450 \mathrm{~m}$ a.s.1 to $1150 \mathrm{~m}$ a.s.l. C. Mean monthly rainfall $(\mathrm{mm})$, potential evapotranspiration $(\mathrm{ETP}, \mathrm{mm})$ and temperature $\left({ }^{\circ} \mathrm{C}\right)$ at the closest meteorological station (Peralejos de las Truchas) averaging the 28 available years (1942-1948; 1962-1975; 1996-2006). D. Mean winter rainfall (Dec-Jan-FebMarch) during the longer available measured period (1962-1975) compared to the NAO index (Cook et al. 2002). Source: National Meteorological Institute (INM)

Fig. 2 Stratigraphic correlation among all the cores used in this study. Correlation is based on sedimentary facies, lightness values (from black to white) and magnetic susceptibility (SI units) measured by the GEOTEK loop and point systems for the longer cores (1A, 2A). The composite lacustrine sequence is obtained from Unit 1 in core $2 \mathrm{~A}$ and Units 2, 3 and 4 in core $1 \mathrm{~A}$. Allocthonous terrigenous layers identified are marked by letters. The presence of sandy and organic-rich layers (indicated by numbers from 1 to 5) on short cores (A2, B) allows transporting two ${ }^{14} \mathrm{C}$ ages to the composite sequence. The percentage of Total Inorganic Carbon (TIC), Total Organic Carbon (TOC) and the ratio TOC/TN (Total Nitrogen) in core TAR04-1A are represented. The available dates are indicated (shaded dates are not included in the age model). Vertical scale is in $\mathrm{cm}$

Fig. 3 Downcore X-Ray Fluorescence data measured by the ITRAX Core Scanner, Xray radiograph and lightness values for the lower 3 meters of the Taravilla Lake 
sequence. The two PCA axis profiles (interpreted as carbonate and siliciclastic input, respectively) are also plotted. The observed terrigenous layers are indicated by capital letters along each unit and the tendency of the measured parameters by arrows. The available dates for that sequence are also indicated (shaded dates are not included in the age model)

Fig. 4 Principal Components Analyses carried out with the X-Ray Fluorescence data from Taravilla Lake sequence. The arrows represent the variables used for that analysis and the numbers (depth value) mark the position of every sample

Fig. 5 Pollen diagram of the Taravilla Lake. Only selected palynological taxa and groups are plotted. Mesophytes curve includes deciduous Quercus, Corylus, Betula, Salix, Ulmus, Tilia, Populus and Juglans. Evergreen Quercus, Oleaceae (Fraxinus, Olea and Phillyrea), Viburnum, Lamiaceae, Ephedra fragilis type, Genisteae, Ericaceae, Cistus, Rhamnus, Myrtus and Thymelaea are the Mediterranean component. Anthropics group is composed by Cichorioideae, Carduae, Asteroideae, Centaurea, Artemisia, Caryophyllaceae, Plantago, Rumex, Brassicaceae, Urticaceae, Geraniaceae and Malvaceae. Finally, as the aquatic component (hydro- and hygrophytes), Apiaceae, Ranunculaceae, Thalictrum, Cyperaceae, Typha, Potamogeton, Myriophyllum and Nuphar are included. Pollen zones, lithological units and flood layers are included.

Fig. 6 Age model of the Taravilla Lake composite sequence. A. Age-Depth graph including the available dates and the values of the Linear Sedimentation Rate (LSR). The historical periods covered and the location in time of the Little Ice Age (LIA) and Medieval Warm Period (MWP) are also shown. Gray area indicates the time interval 
covered by the hiatus. B. Age-Depth graph resulting from excluding the flood layers (note that the resulting LSR is more constant than before). C. Age model including the flood layers again but considering them as instantaneous events. This Age-Depth reconstruction is also included in the A graph as a dashed line and is the age model used for the Taravilla Lake sequence

Fig. 7 Comparison versus time of global reconstructions and paleoflood reconstructions from the Iberian Peninsula. From left to right: (A) constructed series of yearly sunspot numbers as observed by eye in remote times and recorded in historical documents covering the period 165 BC-1918 AD (Vaquero et al. 2002); the 25-year moving average is also shown. (B) Solar irradiance reconstructed from the concentration of fluctuations of ${ }^{14} \mathrm{C}$ and ${ }^{10} \mathrm{Be}$ production rates over the last 1200 years (Bard et al. 2000). (C) Northern Hemisphere temperature anomalies reconstruction (1961-1990 instrumental reference period) based on proxy records and smoothed with a 40 year lowpass filter (Mann and Jones 2003). (D) NAO index reconstructed for the last 600 years from tree-rings and averaged every 25 points (Cook et al. 2002). (E) Paleoflood reconstruction from the Taravilla Lake record indicated by red lines (see text for explanation about the identification and dating of flood layers) and (F) the 25-year moving average. Sedimentary units are indicated (note that Unit 2 is an instantaneous flood event occurring at $1500 \mathrm{cal} \mathrm{yr} \mathrm{AD).} \mathrm{(G)} \mathrm{Number} \mathrm{of} \mathrm{floods} \mathrm{per} \mathrm{decade} \mathrm{in} \mathrm{the} \mathrm{Tagus}$ River (moving average analyses taking a three data interval) (Benito et al. 2003a). The five periods with more flooding episodes are indicated by bands. $(\mathrm{H})$ Reconstruction of dry and wet periods from historical data in the Northern Iberian peninsula (Barriendos and Martín-Vide 1998). The LIA and MWP are marked following (Jones et al. 2001) and the minimum and maximums in solar variability for the last 2000 years following 
(Vaquero et al. 2002) and (Ogurtsov et al. 2002). Shaded area between 800 and 1000 years $\mathrm{AD}$ marks an interval of high solar irradiance that would correspond to the first paleoflood interval in Taravilla record. 


\section{References}

Abrantes F., Lebreiro S., Rodrigues T., Gil I., Bartels-Jonsdottir H., Oliveira P., Kissel C. and Grimalt J.O. 2005. Shallow-marine sediment cores record climate variability and earthquake activity off Lisbon (Portugal) for the last 2000 years. Quaternary Science Reviews 24: 2477-2494.

Aguilar C. and Nealson K.H. 1998. Biogeochemical Cycling of Manganese in Oneida Lake, New York: Whole Lake Studies of Manganese. Journal of Great Lakes Research 24: 93-104.

Bard E. and Frank M. 2006. Climate change and solar variability: What's new under the sun? Earth and Planetary Science Letters 248: 480-493.

Bard E., Raisbeck G., Yiou F. and Jouzel J. 2000. Solar irradiance during the last 1200 yr based on cosmogenic nuclides. Tellus 52B: 985-992.

Barriendos M. and Martín-Vide J. 1998. Secular Climatic Oscillations as Indicated by Catastrophic Floods in the Spanish Mediterranean Coastal Area (14th-19th Centuries). Climate Change 38: 473-491.

Benito G. 2006. Riesgos de inundaciones: tendencias históricas y perspectivas de acuerdo con el cambio climático. Cuaternario y Geomorfología 20: 29-44.

Benito G., Díez-Herrero A. and Fernádez de Villalta M. 2004. Flood response to solar activity in the Tagus basin (Central Spain) over the last millennium. Climatic Change 66: 27-28.

Benito G., Díez-Herrero A. and Fernández de Villalta M. 2003a. Magnitude and frequency of flooding in the Tagus basin (Central Spain) over the last millennium. Climatic Change 58: 171-192.

Benito G., Machado M.J. and Pérez-González A. 1996. Climate change and flood sensitivity in Spain. In: J. Branson, A. G. Brown and K. J. Gregory (eds.), Global continental changes: the context of paleohydrology. The Geological Society of London, London, pp. 85-98.

Benito G., Machado M.J., Pérez-González A. and Sopeña A. 1998. Palaeohydrology and Environmental Change. John Wiley \& Sons Ltd.

Benito G., Sopeña A., Sánchez-Moya Y., Machado M.J. and Pérez-González A. 2003. Paleoflood record of the Tagus River (Central Spain) during the Late Pleistocene and Holocene. Quaternary Science Reviews 22: 1737-1756.

Blum P. 1997. Reflectance spectrophotometry and colorimetry. In: P. Blum (ed.), Physical Properties Handbook. ODP.

Bøe A.G., Dahl S.O., Lie Ø. and Nesje A. 2006. Holocene river floods in the upper Glomma catchment, southern Norway: a high-resolution multiproxy record from lacustrine sediments. The Holocene 16: 445-455.

Bond G., Showers W., Elliot M., Evans M., Lotti R., Hajdas I., Bonani G. and Johnson S. 1999. The North Atlantic's 1-2 kyr climate rhythm: relation to Heinrich Events, Dansgaard/Oeschger cycles and the Little Ice Age. In: R. B. Alley, P. U. Clark, L. Keigwin and R. Webb (eds.), Mechanisms of Global Climate Change at Millennial Time Scales. American Geophysical Union, pp. 35-58.

Bradley R. and Jones P.D. 1993. Little Ice Age summer temperature variations: their nature and relevance to recent global warming trends. 3: 367-376. 
Brown S.L., Bierman P.R., Lini A. and Southon J. 2000. 10000 yr record of extreme hydrologic events. Geology 28: 335-338.

Changnon S.A. and Easterling D.R. 2000. Policies pertaining to weather and climate extremes. Science 289: 2053.

Cook E.R., D'Arrigo R.D. and Mann M.E. 2002. A Well-Verified, Multiproxy

Reconstruction of the Winter North Atlantic Oscillation Index since A.D. 1400. Journal of Climate 15: 1754-1764.

Desprat S., Sánchez-Goñi M.F. and Loutre M.F. 2003. Revealing climatic variability of the last three millennia in northwestern Iberia using pollen influx data. Earth and Planetary Science Letters 213: 63-78.

Eusterhues K., Heinrichs H. and Schneider J. 2005. Geochemical response on redox fluctuations in Holocene lake sediments, Lake Steisslingen, Southern Germany. Chemical Geology 222: 1-22.

González-Sampériz P., Valero-Garcés B.L., Moreno A., Morellon M., Navas A., Machin J. and Delgado-Huertas A. in press. Vegetation changes and hydrological fluctuations in the Central Ebro Basin (NE Spain) since the Late Glacial period: saline lake records. Palaeogeography, Palaeoclimatology, Palaeoecology In Press, Accepted Manuscript.

Gregory K.J., Benito G., Dikau R., Golosov V., Jones A.J.J., Macklin M.G., Parson A.J., Passmore D.G., Poesen J., Starkel L. and Walling D.E. 2006. Past hydrological events related to understanding global change: an ICSU research project. Catena 66: 213.

Hamilton-Taylor J., Smith E.J., Davison W. and Sugiyama M. 2005. Resolving and modeling the effects of $\mathrm{Fe}$ and $\mathrm{Mn}$ redox cycling on trace metal behaviour in a seasonally anoxic lake. Geochimica et Cosmochimica Acta 69: 1947-1960.

Haug G.H., Günther D., Peterson L.C., Sigman D.M., Hughen K.A. and Aeschlimann B. 2003. Climate and the collapse of Maya Civilization. Science 299: 1731-1735. Houghton J.T., Ding Y., Griggs D.J., Noguer M., van der Linden P.J. and Xiaosu D. 2001. Climate Change 2001: The Scientific Basis. Cambridge University Press, 944 pp. Jones P.D., Osborn T.J. and Briffa K.R. 2001. The evolution of climate over the last millennium. Science 292: 662-667.

Kirov B. and Georgieva K. 2002. Long term variations and interrelations of ENSO, NAO and solar activity. Physics and Chemistry of the Earth 27: 441-448.

Knox J.C. 2000. Sensitivity of modern and Holocene floods to climate change. Quaternary Science Reviews 19: 439-457.

Leroy S., Kazanci N., Ileri O., Kibar M., Emre O., McGee E. and Griffiths H.I. 2002. Abrupt environmental changes within a late Holocene lacustrine sequence south of the Marmara Sea (Lake Manyas, N-W Turkey): possible links with seismic events. Marine Geology 190: 531-552.

López-Moreno J.I., Beguería S. and García - Ruíz J.M. 2006. Trends in high flows in the central Spanish Pyrenees: response to climatic factors or to land-use change?

Hydrological Sciences-Journal des Sciences Hydrologiques 51.

Mann M.E. and Jones P.D. 2003. Global surface temperatures over the past two millennia. Geophysical Research Letters 30: doi:10.1029/2003GL017814.

Martín-Puertas C., Valero-Garcés B.L., Mata P., González-Sampériz P., Bao R., Moreno A. and Stefanova V. in press. Arid and Humid Phases in Southern Spain during the last 4000 Years: The Zoñar Lake Record, Córdoba. The Holocene in press. McCarthy J.J., Canziani O.F., Leary N.A., Dokken D.J. and White K.S. 2001. Climate Change 2001: Impacts, Adaptations and Vulnerability. Cambridge University Press, $1042 \mathrm{pp}$. 
Meyers P.A. and Lallier-Vergès E. 1999. Lacustrine Sedimentary Organic Matter Records of Late Quaternary Paleoclimates. Journal of Paleolimnology 21: 345. Moore P., Webb J.A. and Collinson A. 1978-1991. An illustrated guide to pollen analysis. Hodder and Stroughton, London, 216 pp.

Morellón M., Valero-Garcés B.L., Moreno A., González-Sampériz P., Mata P., Romero O., Maestro M. and Navas A. in press. Holocene palaeohydrology and climate variability in Northeastern Spain: the sedimentary record of lake Estanya (Pre-Pyrenean range). Quaternary International.

Morford J.L. and Emerson S.R. 1999. The geochemistry of redox sensitive trace metals in sediments. Geochimica et Cosmochimica Acta 63: 1735-1750.

Nesje A., Dahl S.O., Matthews J.A. and Berrisford M.S. 2001. A 4500-yr record of river floods obtained from a sediment core in Lake Atnsjoen, eastern Norway. Journal of Paleolimnology 25: 329-342.

Noren A.J., Bierman P.R., Steig E.J., Lini A. and Southon J. 2002. Millennial-scale storminess variability in the northeast United States during the Holocene epoch. Nature 419: 821-824.

Ogurtsov M.G., Nagovitsyn Y.A., Kocharov G.E. and Jungner H. 2002. Long-period cycles of the sun's activity recorded in direct solar data and proxies. Solar Physics 211: 371-394.

Oldfield F. 2005. Environmental change: key issues and alternative perspectives. Cambridge press, 263 pp.

Reimer P.J., Baillie M.G.L., Bard E., Bayliss A., Beck J.W., Bertrand C.J.H., Blackwell P.G., Buck C.E., Burr G.S., Cutler K.B., Damon P.E., Edwards R.L., Fairbanks R.G., Friedrich M., Guilderson T.P., Hogg A.G., Hughen K.A., Kromer B., McCormac G., Manning S., Ramsey C.B., Reimer R.W., Remmele S., Southon J.R., Stuiver M., Talamo S., Taylor F.W., van der Plicht J. and Weyhenmeyer C.E. 2004. IntCal04 Terrestrial Radiocarbon Age Calibration, 0 to 26 Cal Kyr BP. Radiocarbon 46: 10291058.

Riera S., Wansard G. and Julià R. 2004. 2000-year environmental history of a karstic lake in the Mediterranean Pre-Pyrenees: the Estanya lakes (Spain). Catena 55: 293-324. Rodò X., Baert E. and Comin F.A. 1997. Variations in seasonal rainfall in Southern Europe during the present century: relationships with the North Atlantic Oscillation and the El Niño-Southern Oscillation. Climate Dynamics 13: 275-284.

Rumsby B. and Macklin M.G. 1996. River response to the last neoglacial (the "Little Ice Age") in northern, western and central Europe. In: J. Branson, A. G. Brown and K. J. Gregory (eds.), Global continental changes: the context of paleohydrology. The Geological Society of London, London, pp. 217-234.

Schnurrenberger D.W., Russell J.M. and Kelts K. 2003. Classification of lacustrine sediments based on sedimentary components. Journal of Paleolimnology 29: 141-154. Simón J.L. 1989. Late Cenozoic stress field and fracturing in the Iberian Chain and Ebro Basin (Spain). Journal of Structural Geology 11: 285-294.

Thorndycraft V.R. and Benito G. 2006. The Holocene fluvial chronology of Spain: evidence from a newly compiled radiocarbon database. Quaternary Science Reviews 25: 223-234.

Thorndycraft V.R., Hu Y., Oldfield F., Crooks P.R.J. and Appleby P.G. 1998. Individual flood events detected in the recent sediments of the Petit Lac d'Annecy, eastern France. The Holocene 8: 741-746.

Trigo R.M., Pozo-Vázquez D., Osborne T., Castro-Díez Y., Gómiz-Fortis S. and Esteban-Parra M.J. 2004. North Atlantic Oscillation influence on precipitation, river 
flow and water resources in the Iberian peninsula. International Journal of Climatology 24: 925-944.

Valero-Garcés B.L., Delgado-Huertas A., Navas A., Edwards R.L., Schwalb A. and Ratto N. 2003. Patterns of regional hydrological variability in central-southern

Altiplano $\left(18^{\circ}-26^{\circ} \mathrm{S}\right)$ lakes during the last 500 years. Palaeogeography,

Palaeoclimatology, Palaeoecology 194: 319-338.

Valero-Garcés B.L., González-Sampériz P., Navas A., Machín J., Mata P., DelgadoHuertas A., Bao R., Moreno A., Carrión J.S., Schwalb A. and González-Barrios A.

2006. Human impact since Medieval times and recent ecological restoration in a

Mediterranean lake: the laguna Zoñar (Spain). Journal of Paleolimnology 35: 441-465.

Valero-Garcés B.L., Moreno A., Navas A., Machín J., Delgado-Huertas A., González-

Sampériz P., Schwalb A., Morellón M. and Edwards R.L. in press. The Taravilla Lake and Tufa Deposits (Central Iberian Range, Spain) as paleohydrological and

paleoclimatic indicators. Palaeogeography, Palaeoclimatology, Palaeoecology.

Vaquero J.M. 2004. Solar signals in the number of floods recorded for the Tagus river basin over the last millennium. Climatic Change 66: 23-26.

Vaquero J.M., Gallego M.C. and García J.A. 2002. A 250-year cycle in naked-eye observations of sunspots. Geophysical Research Letters 29:

doi:10.1029/2002GL014782.

Verschuren D., Laird K.R. and Cumming B.F. 2000. Rainfall and drought in equatorial east Africa during the past 1,100 years. Nature 403: 410-413. 


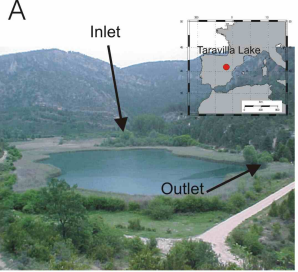

B

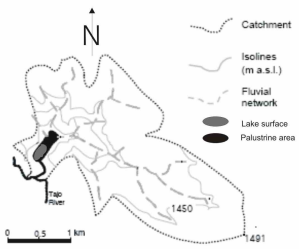

C

D

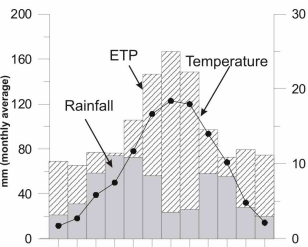

JAN FEB MAR APR MAY JUN JUL AUG SEP OCT NOV DEC
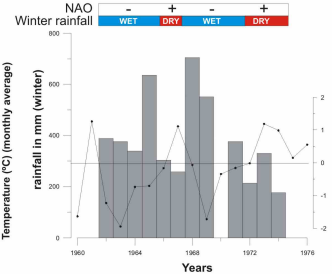

Figure 1 


\section{Core A2}

$\%$ Org. Matter

4812162024

\section{Core B}

$\%$ Org. Matter

4812162024
1716-1891 (1) (1)

o 1020304050 $\%$ Sand 1474-1664

Facies 1

Facies 2

Facies 3 - (3) Correlation layer 1474-1664 Cal age (yr AD)

\section{TAR04-2A}

Lightness

20406080100
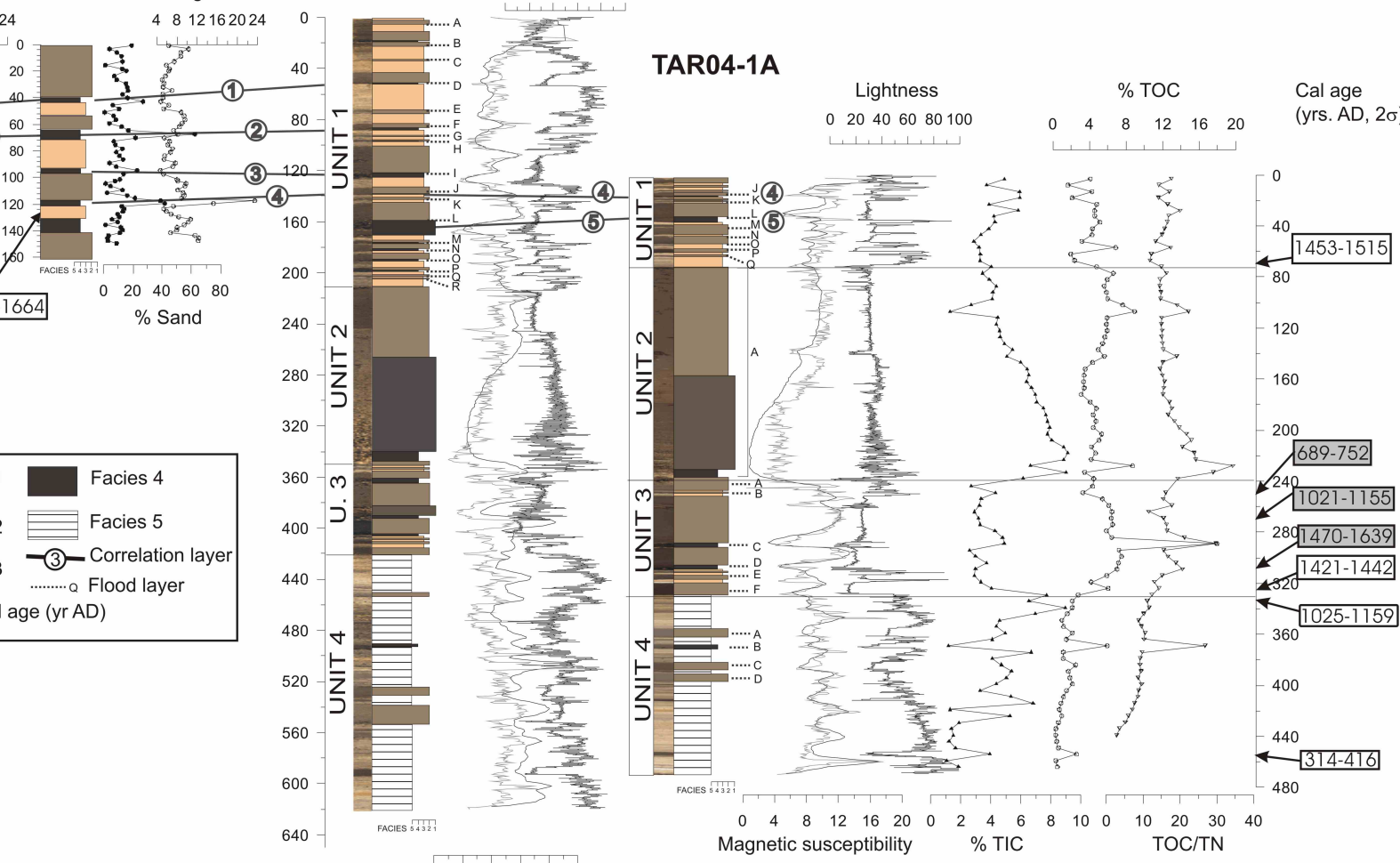
- Siliciclastic input $\rightarrow$

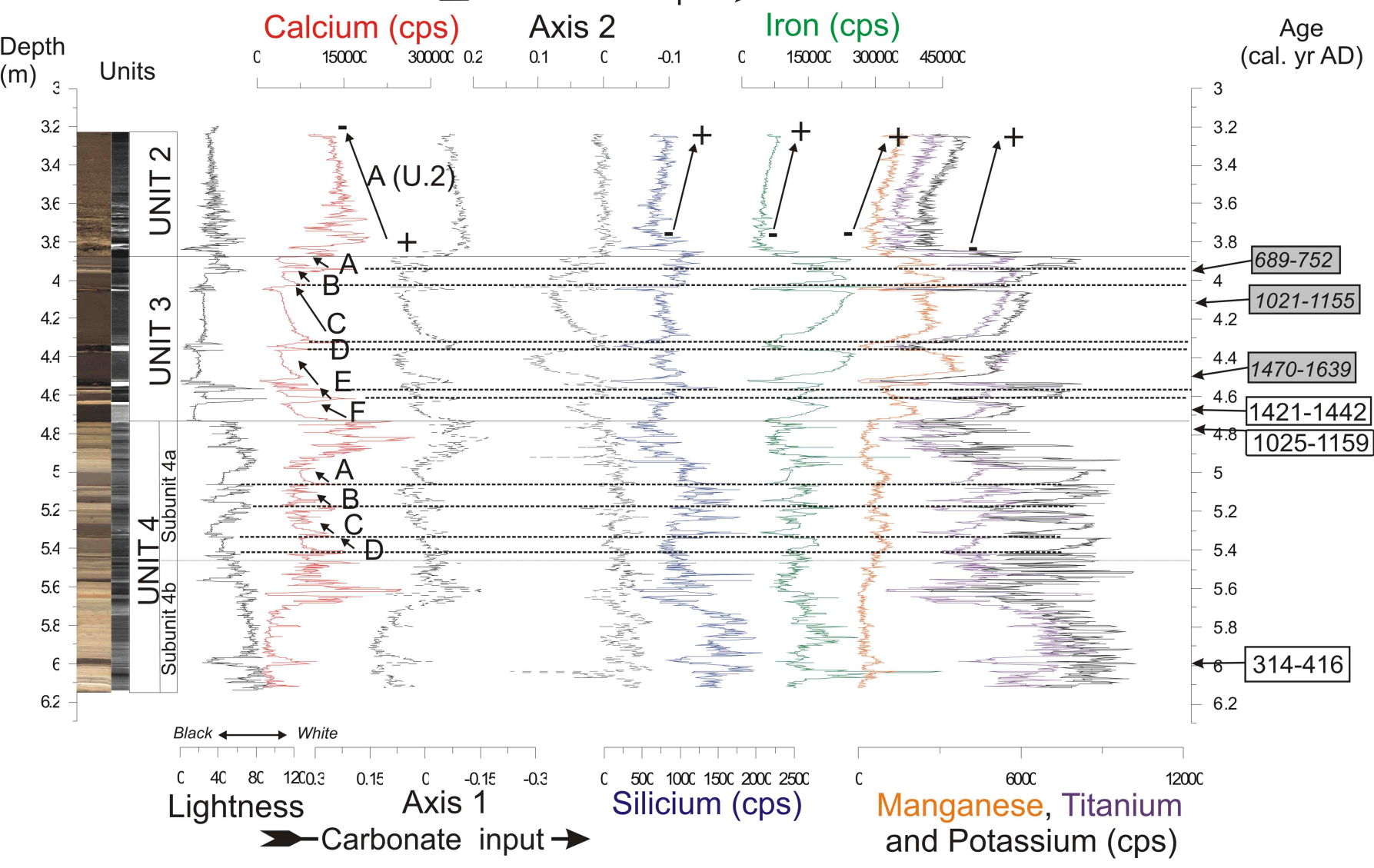

Figure 3 


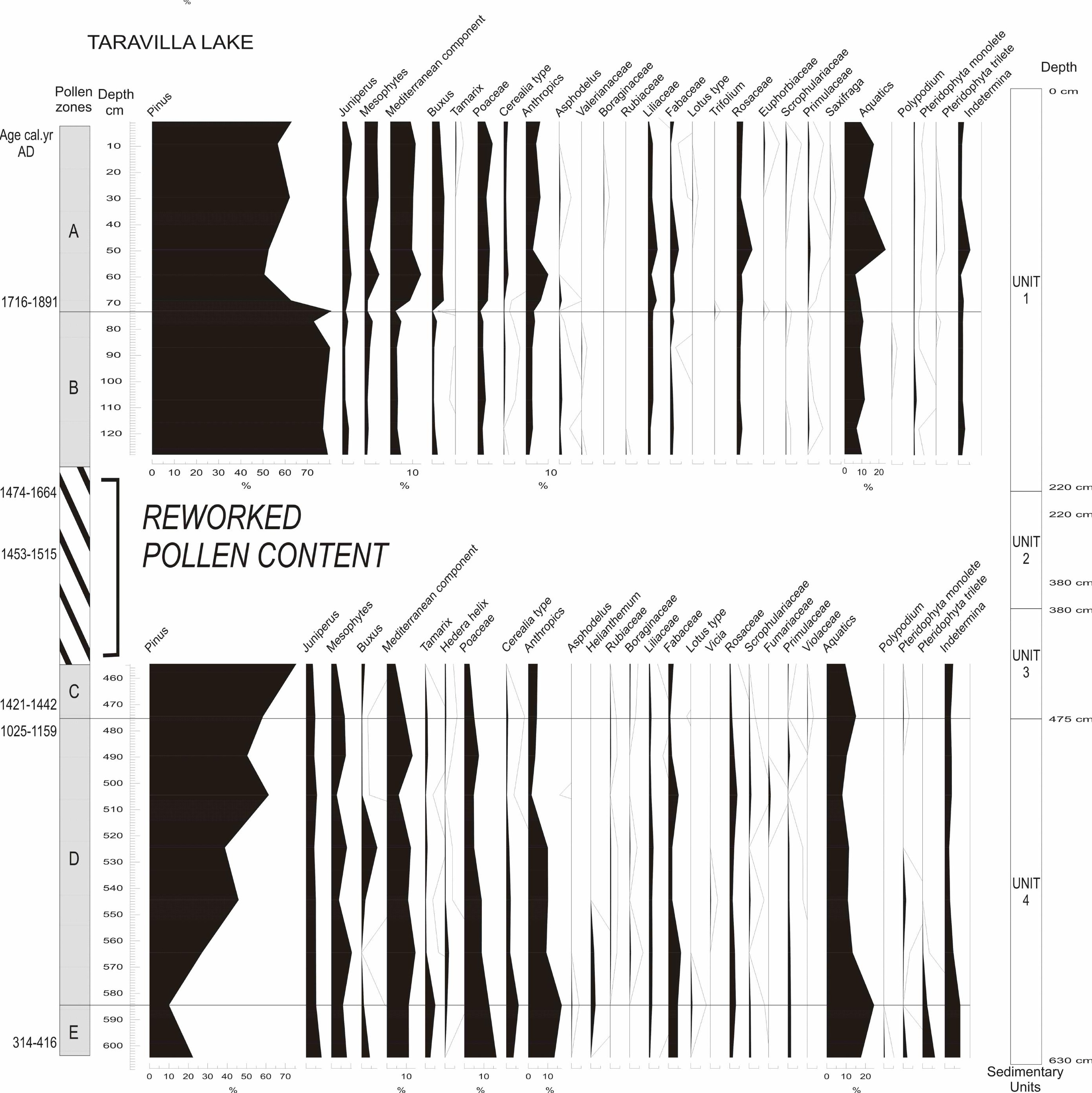




\section{PALEOFLOOD
RECONSTRUCTIONS}

Solar irradiance

(Bard et al., 2000)
NAO index

(Cook et al., 2002)
Age (cal. yr AD)

2000

1900

1800

1700

1600

1500

1400

1300

1200

1100

1000

900

800

700

600

500

400

300

200

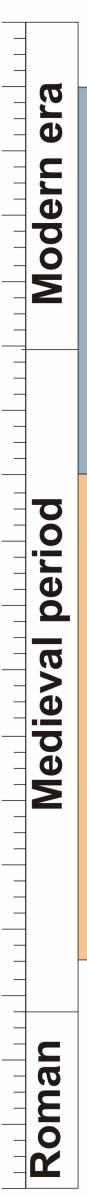

Taravilla lake paleoflood record (this study)
Number of floods per decade

(Benito et al., 2003a)
Floods/Droughts

Mediterranean

(Barriendos et al., 1998)
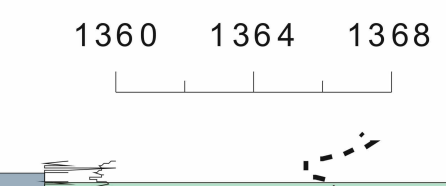

$\begin{array}{llllll}-0.4 & -0.2 & 0 & 0.2 & 0.4\end{array}$

\section{$\begin{array}{llll}0 & 4 & 8 & 12\end{array}$}
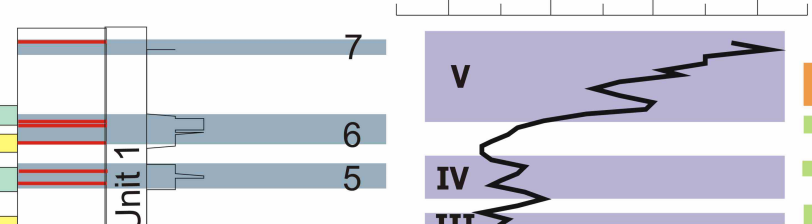

4

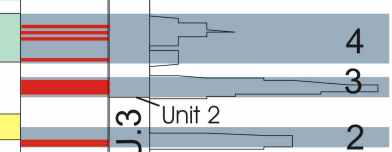

II
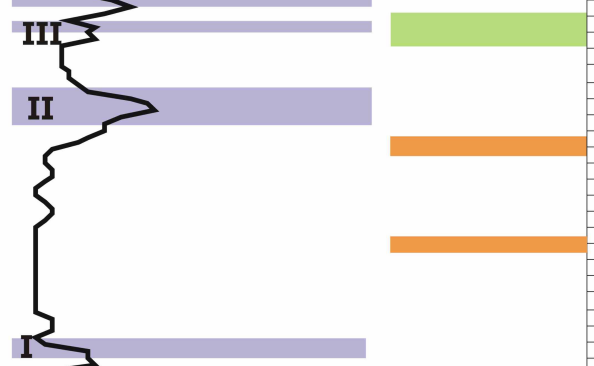

.

?.

Dै Wolf

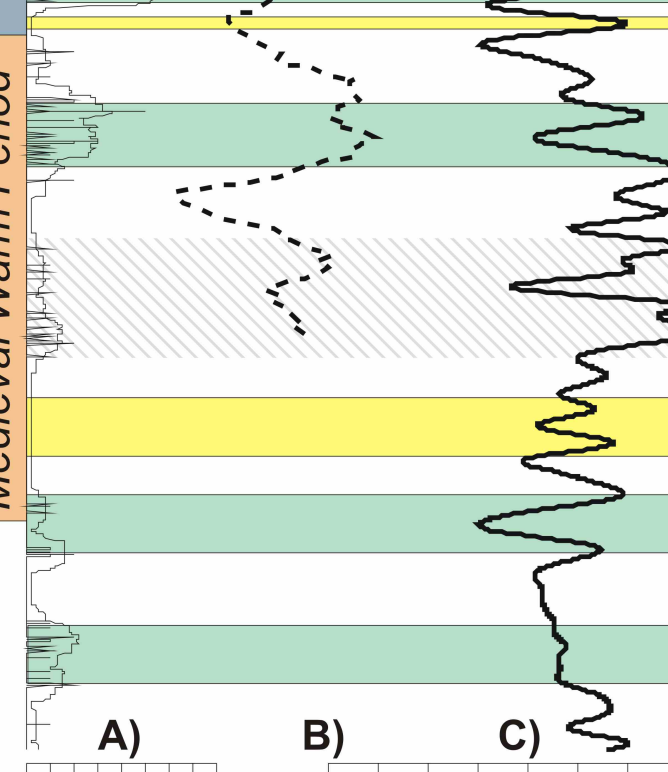

Medieval
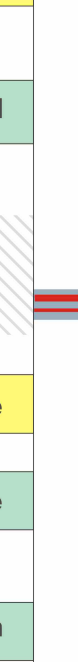

$\begin{array}{lllll}0 & 2 & 4 & 6 & 8\end{array}$

$-0.5$

$-0.4-0$.

$\begin{array}{lll}-0.3 & -0.2 & -0.1\end{array}$

D)

Late Roman

Sunspot number Northern Hemisphere (Vaquero et al., 2002)

Temperature

(Mann and Jones, 2003)
Figure 7 